\title{
Chapter 8 Competences and Learning Profiles of Digital Age's Students
}

\author{
Ana Loureiro \\ Polytechnic Institute of Santarém, Portugal \& University of Aveiro, Portugal \\ Inês Messias \\ Universidade Aberta, Portugal
}

\begin{abstract}
In the connected world we live in today, people no longer look for information only in formal places. Internet has become a place of choice to gather information. Social networks have grown from places for socialization to platforms where knowledge is created and shared, where connectivity and collaboration are natural. Many people look at the web as a place for learning, using it to create a network which allows them to gather, select, share, reshape ideas and create knowledge to then replicate on social networks. Students' learning profile is becoming more proactive in the search for information and constructing valid knowledge. The demands of the information age raise the necessity of students to acquire different skills and competences - 21st century skills. This chapter aims to present the different students' learning profiles and the type of learning environments available online.
\end{abstract}

\section{INTRODUCTION}

Today's society is considered to be digital, due to the proliferation of computer and communication technology. Computers, cell phones and Internet have become more accessible for personal use, and a requirement of the workplace. Castells (2005) states: "the network society is not the emerging social structure of the Information Age: it already configures the nucleus of our societies". In the past few years academic researchers developed various studies that show "the commonality of this nucleus across cultures, as well as the cultural and institutional differences of the network society in various contexts."

Students learning processes and profiles have changed with digital technology, no longer relying only in formal learning contexts for acquiring knowledge, they became more proactive in their search for information and turn to the contents

DOI: 10.4018/978-1-5225-0039-1.ch008 
they can find in the Internet. The search for online courses has grown and it's not showing signs of stopping, more than one infour education students now take at least one course online (Allen \& Seaman, 2010). Students are in a continuous process of learning, through their personal networks and connections they update throughout their lives. Learning is no longer formal, it is informal, non-formal and natural. It occurs in several and different contexts.

Social and collaborative web are making changes in the way students learn, especially in a distance learning format. Students use simultaneously diverse types of media in their daily lives, therefore to them traditional teaching is poorly stimulating. Education is in need of change, becoming more personalized, reflexive, social connected, involving and permitting instant gratification to embrace both native and digital immigrants (Prensky, 2001).

Social Web, virtual environments and Web 2.0 tools, by nature, are spaces that allow a closer contact between users, enhancing cooperation, collaboration and socialization among them. Students daily use it, but to actually learn and retain knowledge available on the web there is the need of acquire digital skills (e-skills), social (soft) skills and be digitally literate.

This chapter aims to know if and how these competences and access to digital and virtual tools are changing students learning processes and profiles, and how the learning that occurs in VLE (Virtual Learning Environments) and PLE (Personal Learning Environments) are allowing them to be more participative in constructing their knowledge. To achieve this goal a literature review will be presented along with examples about the different students' profiles, the different forms of learning, of personal and virtual learning networks and connectivism and how these impact e-learning contexts.

\section{BACKGROUND}

Students need to acquire certain skills and competences, specific of a digital and connected society in order to effectively benefit from e-government, e-learning and e-health services, and participate actively in the knowledge society as co-creators, and not simply consumers, as highlighted by the Europeane-skills strategy (McCormack, 2010). To only possess hard skills (that comes with experience and formal education) may not be enough to get a job. Besides e-skills and e-literacy competences, soft and social skills are also a demand. These skills and competences can be practiced and enhanced in virtual environments - which are by nature social and collaborative spaces. Students have access to virtual worlds with role-play and simulations, social networks and a wide range of web 2.0 tools, which allow them to practice and develop some of these skills and competences. In an e-learning format, which normally means to study at a distance of 'brick and mortar' tertiary institutions, e-skills are a demand. And in spite of what one might think, to learn at a distance is not by itself a synonymous of being isolated from the world; on the contrary, to be able to socialize and communicate is crucial, so that the student can maintain motivated, and also so that he can take advantage of collaborative tools to create and share knowledge. Therefore the acquisition of soft and social skills are mandatory.

Web 2.0 and 3.0 is changing the way students learn. It has already changed the way they interact with each other and with the world. The social web is part of their daily lives, giving them the possibility to connect and share with peers their personal lives, through social networking. But they don't only use Internet socially, they use it to read the news, listen to music and also gather information about school related subjects. In fact students are used to utilize simultaneously diverse 
types of media, giving them a new profile as students, who find traditional teaching uninteresting. E-learning environments, such as VLE or PLE are now complementing traditional teaching, giving access to live conferencing, video sharing, and other collaborative tools that permit students to organize their learning spaces as it suits them best.

Students' proactiveness in using the web to gather information is no longer an issue to the teacher; students are already doing it. The teacher's role changes, and now includes giving competences to guide them in knowing where, how and what information to select from all what its available.

A crucial competence is that of networking (i.e. being connected). The more relevant connections one has in one's study field, the more relevant information one accesses. Therefore, social networks play an important part in gathering sources for valid contents.

\section{MAIN FOCUS OF THE CHAPTER}

\section{Forms of Learning}

According with Organisation for Economic Cooperation and Development (OECD) there are three forms of learning - Formal, Informal and Non-formal. Besides these three we can also learn in a Natural form.

We assume as Formal learning all the learning that occurs in classroom contexts (either in presence or online), which requires the presence or mediation of a teacher, sometimes recurring to additional tools. According to Cross (2009), Learning is formal when someone other than the learner sets curriculum. Typically, it's an event, on a schedule and completion is generally recognized with a symbol, such as a grade, gold star, certificate or check mark in a learning management system. Formal learning is pushed on learners. This form of learning occurs essentially when a student attends to class in a formal institution. And is the one we use for most of our student life as it may confer a formal recognition in the form of a certificate or diploma.

Informal learning can be defined as a result of doing daily activities. It is not organised nor has a formal recognition, for it can be made during daily tasks, such as observation, asking questions, trial and error, and sometimes it can even be accidental. According to OECD, Informal learning is never organised, has no set objective in terms of learning outcomes and is never intentional from the learner's standpoint. Often it is referred to as learning by experience or just as experience. Therefore we can consider it as all learning that we acquire without intention, but even so it able us to know something we didn't know before.

The definition of Non-formal learning is not consensual, for it over lapses the definition of formal and informal learning. To most authors it can be referred as semi-organized and intentional, meaning it may or may not have organised activities but that it has a learning objective. Coraldyn and Bjornavold (2004) state that it consists of learning embedded in planned activities that are not explicitly designated as learning, but which contain an important learning element. Considering this, most of the adult learning is being done this way, because it is flexible and has tasks that can be done at your own pace. This form of learning, in order to avoid an over lapse, according to the OECD, must be strictly defined to be operational, by being mutual exclusive. An example of a nonformal form of learning can be the PLEs. In a PLE the individual organizes their own learning environment according with their needs.

In a Natural form of learning, the learning process is individual and occurs because the learner wants tolearn independently of the time/place they are in, at their own pace and in an autonomous way (Bettencourt, 2010). Therefore to learn in a Natural way depends on the level of socialization an individual can carry out - more the socialization more the person will learn (Loureiro, Santos \& Bettencourt, 2012), therefore, individuals have to 
be embedded in a community of sharing (Bettencourt, 2010). A good example of a Natural learning context can be virtual worlds - such as Second Life $^{\circledast}$ (http://secondlife.com/). In this particular 3D immersive virtual world, learning processes are focused in communities of sharing. For learning to occur and knowledge to be achieved each learner has to immerse himself in the community becoming part of it. Another example of natural learning context can be when an individual goes to a foreign country in order to learn a new language by immersing in the community of the country.

In Figure 1 we resume the four forms of learning and how they relate with one another.

\section{Digital Literacy}

Digital literacy or e-literacy is a group of competences that allows an individual to acquire knowledge through digital processes. It refers to the awarenesses, skills, understandings, and reflective approaches necessary for an individual to operate comfortably in information-rich and IT-enabled environments. (Martin \& Ashworth, 2004)
To better understand digital literacy, first is important to understand the literacy concept - the ability to comprehend what we read, to give meaning, understand written language. Not having any relation to the fact of one being educated or not.

So being digital literate does not refers only to the capability to use a computer or an email, but to the capability to gather, understand, interpret and share information available in all digital media. Being digital literate gives us the ability to communicate and work more efficiently, because it involves understanding how all digital devices work and how they can be used to interact with society. Digital literacy is a person's ability to perform tasks effectively in a digital environment (...) Literacy includes the ability to read and interpret media, to reproduce data and images through digital manipulation, and to evaluate and apply new knowledge gained from digital environments. (Jones-Kavalier \& Flannigan, 2006)

According to the California ICT Digital Literacy Assessments and Curriculum Framework, to be digitally literate involves: (i) to have access to information and know how to collect it in

Figure 1. Forms of learning and their relation

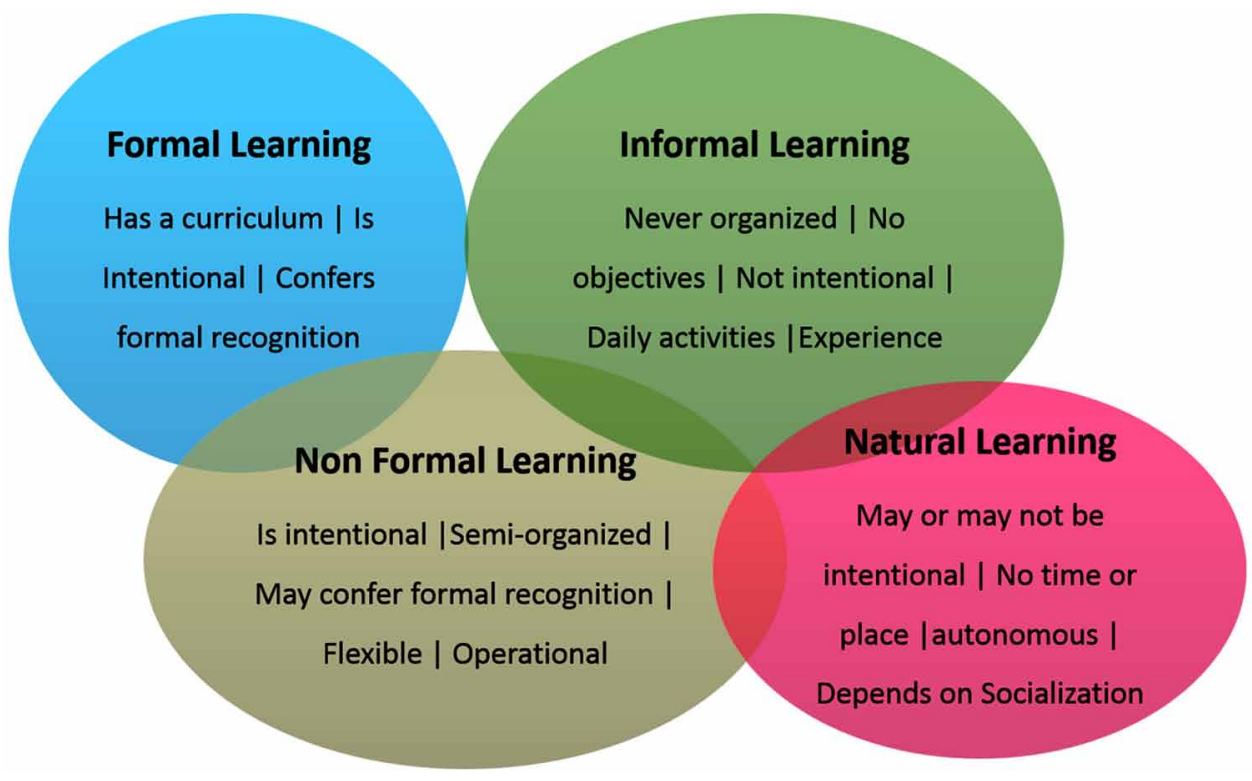


digital environments, (ii) to manage and organize information for future application, (iii) to evaluate, integrate, interpret and compare information from multiple sources, (iv) to create and generate knowledge by adapting, applying and authoring information, (v) and to communicate information to various audiences and through use of an appropriate medium. For that purpose it is crucial to have information literacy skills. The information literacy comprehends knowledge of one's needs and problems with information, and the ability to identify, locate, evaluate, organize and create, use and communicate effectively the information to solve existing problems or issues (Figure 2). According with the American Library Association (2010), information literacy is the set of skills needed to find, retrieve, analyze, and use information (...) Ultimately, information literate people are those who have learned how to learn. They know how to learn because they know how knowledge is organized, how to find information, and how to use information in such a way that others can learn from them. They are people prepared for lifelong learning, because they can always find the information needed for any task or decision at hand.
Being in the possess of the above mentioned competences, a person will be able to learn, work and interact effectively in the digital networked society, and also have the life-long ability to locate, evaluate, use and create information - in a summary form: to generate knowledge (Figure 2)

\section{E-Skills}

In a digital society the demand for e-skills has been growing fast. These are crucial to boost competitiveness, productivity and innovation as well as the professionalism and unplayability of the workforce (McCormack, 2010).

There is more to e-skills than the basic ICT skills. Actually we can find three major types of e-skills: (i) ICT practitioner skills; (ii) ICT user skills; and (iii) ICT business skills.

ICT practitioner skills are those required to make research, design and develop, manage and maintain ICT systems. Most of the times to do this its required profound knowledge of ICT systems, hence one must have some level of academic formation. ICT user skills is the most common of all. It relates to the capabilities that allow an individual to use the ICT systems and devices,

Figure 2. Information literacy

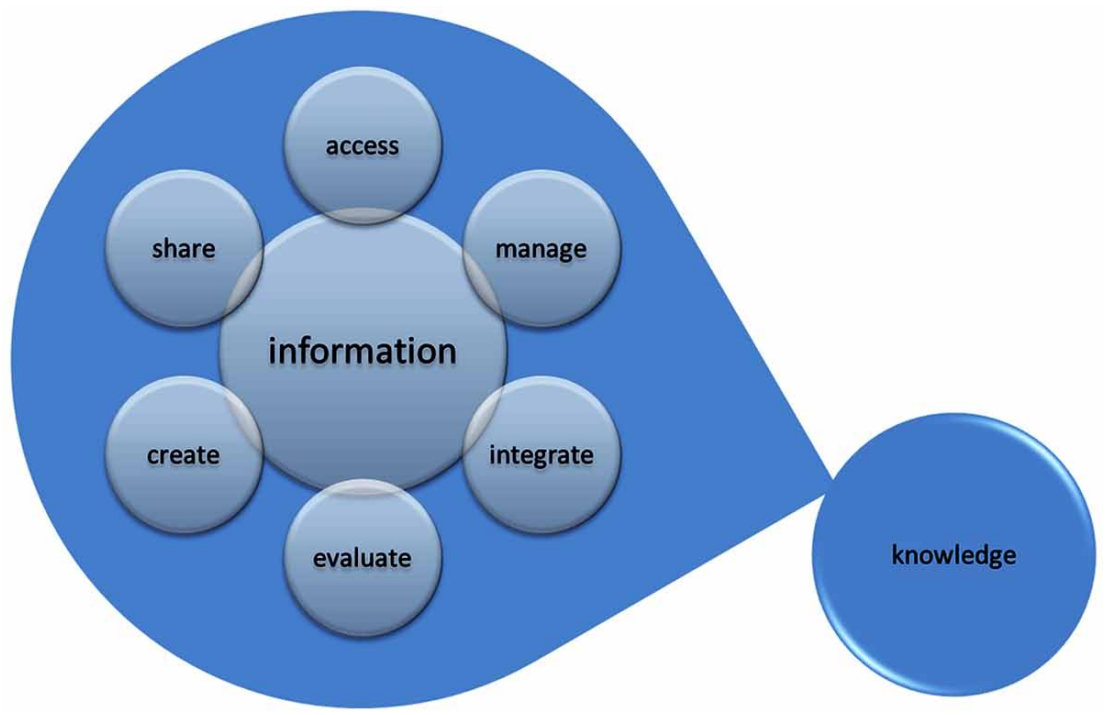


giving the user the confident and critical use of ICT to support their work, leisure, learning and communication. ICT user skills also cover the use of common software tools. E-Business skills relate to the capabilities one needs to exploit opportunities provided by ICT, notably the Internet, to enhance the efficiency and effectiveness of an organization performance on different grounds; this type of skill includes also the capability to explore possibilities for new ways of conducting business processes and/or to establish new businesses.

According with Lenvin, so that students acquire the needed e-skills, some action is needed. Therefore Tertiary education is the right place to start, because it is the right context to think of generating not only the brains that Europe needs, but also the minds that it deserves (cited in McCormack, 2010).

Students with e-skills are capable of critical thinking, multitasking and collaborating in team work. As McCormack (2010) says, our society needs e-skilled people to provide the infrastructure and e-skilled people to use it. An e-skilled society is thus a precursor to a knowledge-based society.

\section{Soft Skills and Social Skills}

Besides hard skills students also need to acquire soft skills. Soft skills are personality traits, qualities and also social skills which every student possesses although in varying degrees - it is related with emotional intelligence. On the other hand social skills are the set of skills that allow students to communicate, relate and socialize with others. Socialization is a key factor for learning - and that means connecting, communicating, interacting and establishing relationships. According with Schultz (2008), the most important soft skills are related with:

- $\quad$ Communication skills (proficiency in spoken and written language as well as to know what to say and how to say it in different occasions);
- Critical and structured thinking along with analytical skills (problem solving capability); and

- Creativity (ability of thinking out of the box, often needed to find innovative approaches to problem solving).

In most Tertiary curricula students graduate with a high level of knowledge in a certain field - hard skills. But nowadays most companies also look for soft and social skills. Soft skills are what shapes our personality, enable social competences, for they complement the technical skills required to do a job, and so are equally as important as to have technical and scientific knowledge.

\section{Students Profiles in the Connected Age}

Having grown up surrounded by digital technology, from television to computers and game stations, cell phones and, more recently, tablets, today's youth are used to digital and to use several devices simultaneously. We could dare to say that today's students are digitally-savvy, utilizing any sort of digital device almost intuitively, and the skill of using several devices at the same time makes them also expert in multitasking. In addition to these characteristics, the youth of today have in common a set of skills that unites them, being possible to draw a profile of the youth of today. But more than that, it is important to know whether this profile alters their characteristics as students. Given the influence that the web 2.0 and digital tools have had on the profile of today's youth it is necessary to understand how these contribute to their student's profile, what are their characteristics, what skills they need to develop to be useful for their professional future and what do they seek for out of university education today.

There are specific terms for the various generations of students. Some older, some more current terms, that describe a generation increasingly linked to digital. Jones and Shao (2011) list some of the most referenced terms such as Millennials, 
used by Howe and Strauss (1991, 2000 and 2003), Net generation, defended by Tapscott (1998 and 2009). Obliger and Oblinger (2005) mention the terms Digital Natives / Digital Immigrants used by Prensky (2001a, 2001b, 2009 and 2010) and Palfrey and Gasser (2008), the term Generation $Y$, described by Jorgensen (2003), Weiler (2005) and McCrindle (2006), the term IM Generation used by Lenhart, Rainie and Lewis (2001), the term Gamer generation, described by Carstens and Beck (2005) and Homo Zappiens defended by Veen (2006). Shao states that each one of the terms presented by these authors differ depending on the social context in which they are involved, but similar terms arise between them. As for more modern terms the author refers to two generations: Google generation, with the term assigned by Rowlands et al. (2008) and $i$-Generation identified by Rosen (2010). In order to better understand the evolution of the several generations we present them in a chronological order (Figure 3).

It thus becomes important to define some of the terms discussed, so that it is possible then to define a potential profile for the higher education student, in order to adopt appropriate teaching strategies to their learning profiles.

The term Millennials first appears in 1991, by Howe and Strauss, describing this generation as those born after 1982 . The authors identify several features that give not only the influence of digital technologies existing at the time, as society and the economic environment they lived. Optimistic, with preference for teamwork, successful in studies and, with appetites to follow rules, heroic, collegial and rationalists, with strong values of community and technology. These last two, seen by Jones \& Shao (2011) as the two most interesting values of this generation. For the same age group, other authors suggest a different term: Net generation. Rosen (2011) says the millennials prefer this term because it is more specific as to the influence the internet has had in this generation. To this author the Net-geners, born between 1980 and 1990, never lived in a world without the Internet, mobile phones or computer games.

Although Rosen (2010) overlaps the definitions of Digital Native with the $i$-Generation, we think it is more accurate to separate these terms, as in the European case the use of digital devices from Apple has had a wider adhesion only recently due to a possible technological gap relative to the US case, although the use of other digital devices is a reality that already happens for a longer time.

Prensky (2001) defines Digital Natives as those who grew up using digital technology, arguing that the skills they have acquired due to this technology (capable of multitasking, impatient due to the habit of having immediate access to information, preferring visual information and hypertext to books, working best in networks, enjoying being motivated and rewarded) have contributed to the change in their way of thinking and studying, since they are native speakers of the digital language. It is now clear that as a result of this ubiquitous environment and the sheer volume of their interaction with it, today's students think and process information fundamentally differently from their predecessors. (Prensky, 2001a). Assuming that the way of thinking of digital natives has changed, Prensky, concludes that the structure of their brains also changed, developing more some areas, such as visual and spatial, over others, such as the capacity for reflection and transforming the experienced in acquired knowledge.

Figure 3. Proposed chronological order for generations

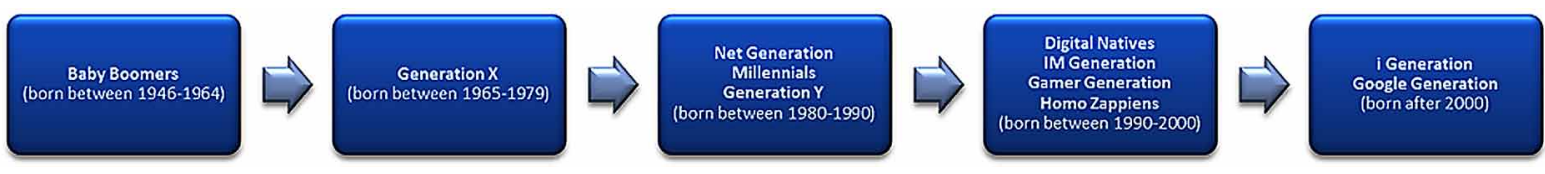


As for the definition of $i$-Generation attributed by Rosen (2010) it is more specific, since the " $i$ " is due to the wide use they make of iPods, iTunes, Wii, iChat, iPhone and iHome. The author suggests that this term can be applied to those born after 1990, however, for the general European population, the wide use of these devices arises only after 2000. Thus, in the European case those born after 2000 can be called $i$-geners, and we expect that they begin to arrive at universities in about four or five years, bringing with them their particular learning profiles. Thus, this is the students' profile teachers need to start preparing for.

The $i$-Generation is described by Rosen (2010) as having the following characteristics:

- Grew up with Technology: Literally have contact with digital technology from birth, being the center of their lives. Learned early to surf the internet, some even before knowing how to read and write properly, to play online and watch videos. In adolescence research and consult the web with ease to both issues related to school, and leisure. Many had never consulted an encyclopaedia on paper or been to a library. Have the most current gaming consoles, which they use daily. For them, a world without internet, phone or tablet is not imaginable.

- Constantly Connected: The youth of iGen are online since they rise until they lie down, some remain attached even after going to bed, putting cell phones just silent. According to studies conducted by the author, young people today spend on average 21 hours a day online. This high number is only possible because most of the time they are online they are not focused only on the computer, but doing multitasking.

- Multitasking: Many young i-Gen study, listen to music, watch TV, talk, do meals, always online, always reachable, even though they are doing other tasks. Communication and being contactable is a central part of their lives, as well as playing a part of their daily routines. Not only do they believe they can accomplish more than one task at a time with rigor, as they become annoyed when are bound to be exclusively focused on a task. Most teens, simply can not unitask. It is too simple and too quiet and too restricting. (Rosen, 2010).

- Always Contactable: Communication is so important to the youth of i-Gen that the tools they use are mostly for that reason. The phones beyond talking and texting provide access to social networks and the computer can now be used to make video calls and phone calls. They are always updated with the latest versions of mobile phones, tablets and computers, always with new applications that allow you to communicate anywhere, in any circumstance, with several people at once.

- Online Social Interaction: Social networks are seen as a means to initiate and maintain friendships with people with common interests. This need to maintain contact in online social networks can be explained due to lack of time caused by filled school schedules, and by the more competitive school that requires hours of study and various extracurricular activities in which they participate. Young people have little time to socialize face-to-face, leading to online socialization. Nearly all belong to more than one social network, which they visit daily and take part in various posts, talk privately or in groups. They even feel less embarrassment chatting online than at presence, being more interactive, direct and communicative.

- Creating and Sharing Content: The youth of i-Gen spends a lot of time creating and sharing content on social networks. They create their own Websites, blogs, videos, share photos, thoughts and opinions. 
- Unique Learning Style: They learn best by touching, moving, doing, experiencing. When you see a teen ignore the manual for his new video game console and simply start pressing all the buttons, there is no doubt that there is a decided preference for tactile/kinaesthetic learning. (Rosen, 2010).

- Need Constant Motivation: Are motivated by encouragement. Are not satisfied with just rewards at the end of the tasks, they need to hear that they are doing a good job during and after the task. Computer games give them that satisfaction as well as do the opposite when they lose the game.

- $\quad$ Strong Family Ties: They enjoy living with their parents and even say that spending time with family makes them happy.

- Confident: They see themselves achieving their professional goals without any doubts and this feature makes them motivated and interested in learning, thus the environment is stimulating and the topic of their interest.

- Open to Change: They enjoy all that is new and innovative, being curious by nature.

- Collective Reflection: As they enjoy socializing they like this aspect to be present in school, so closing the dialog confining it only to the area of the classroom can be demotivating.

- Instant Gratification: Due to the rapidity, characteristic of digital tools, they expect the adult / teacher to answer their questions and curiosities alike.

Still according to Rosen (2011) no one has all the characteristics of a specific generation, each of us can present a profile with mixed characteristics, from different generations, provided by the context and environment in which we grow. Still, the author suggests a chronological order for generations: 1) Baby Boomers (1946-1964); 2) Generation $X$
(1965-1979); 3) Generation Net (1980 - 1989) prices; 4) i-Generation (after 1990). And though the author demarcates the youth of i-Gen as all the born after 1990, in Europe, for the majority of the population, by this time, the circumstances presented by the author had not yet been verified. Indeed, only in the last 10 years or so, it might be said that young Europeans are living in this context, with the necessary means to acquire these features that are part of the i-Generation. Thus we propose the following timeline, slightly modified:

In other hand Rowlands et al. (2008) propose the term for the Google generation to those born after 1993, having grown up surrounded by the internet. While this description, initially, is much simplistic, the authors consider some features for this profile, such as feeling more comfortable with a computer than with pen and paper, or using search engines, like Google, to do research instead of safer means, where they can be sure of the validity of the content. These same authors suggest that many young people do not attend libraries, or have the notion that today there are diverse libraries with digital files. They refer these young people preferring quick searches to slower ones but more effective on the validity and therefore, one can conclude that the contents they absorb are most often superficial. Given these initial data the authors analyse some of the features other authors attribute to the youth of the digital age:

- They Are More Competent with Technology: The authors state that it is necessary to take into account that most young people use simple applications, while the older ones tend to use more complex applications, often for professional reasons.

- They Have High Expectations for ICT: According to the authors most young do, because they take into account the impact that these have had not only in society as well in the business world too. 
- They Prefer Interaction and Are Proactive: The authors believe most young people shown to have these characteristics and can be proved given the choice of tools and applications that they make.

- They Prefer to Communicate through Written Messages: The authors state that this characteristic is difficult to prove since today, apart from face to face conversation, text message are the most financially affordable.

- They Master Multitasking: Though there are no studies to prove this assertion, the authors believe that being exposed to various types of media may develop good skills in processing information in parallel.

- View Teaching with Technology access as More Motivating: The authors believe that for some young people this is true, however, warn that the use of technology in the classroom should be done carefully and properly.

- They Prefer Visual Information: Although confirming this feature the authors note that text still plays a very important role.

- Require Immediate Response: The authors state that there are no studies to support this feature, which sees young people as intolerant and impatient.

- It Is More Important What They Read Online than What They Learn in Formal Education or with Authority Figures: The authors doesn't believe this is true, because early on students learn to rely on textbooks and knowledge of teachers. They suggest that this may arise from some personal comments of young rebels.

- They Have the Need to be Always Online: Authors attribute this feature to all of us and not just the Google generation.

- They Are the Generation of the Cut and Paste: This feature is given as true, and the authors state that there are unfortunately more and more problems with plagiarism.

- Learning by Trial and Error: Although the authors do not believe that this feature is real, they present no concrete example.

- They Prefer Summaries to Original Texts: These authors believe it to be true not only for the youth but also for adults. They refer the increasing tendency, and state that even researchers read the abstracts of articles to make a pre-selection of the full article. They believe that the whole society is less intelligent: Society is dumbing down.

- They Are Natural Born Researchers: As stated above, although many young people do online, the authors believe that the surveys they do are in their majority superficial and done only using the online search engines.

- They Think It's All on the Web and It's All Free: The authors believe that unfortunately some people still think that this is true, but do note that most do not even know of the existence of online libraries.

- Do Not Respect Intellectual Property: Authors state that this is not entirely true, since most advocate open source, but many do plagiarism regularly.

With these data in mind, the authors propose the flexible profile, and refer that we all have one or another of the features presented, regardless of our age. They argue that we all use the web 2.0 and that while the younger more easily adopt new applications, the older people have been following the trend, and were even nicknamed Silver Surfers. In most of the European population, although this may happen in the active population, which for professional reasons have felt the need to use web 2.0 , the population over 60 years old, with fewer studies demonstrate not to have technological skills to use the web autonomously. 
When considering the profile employers demand, Van Dorp and Monteros (2010) suggest three student profiles: academics, entrepreneurs and employable. They describe students with academic profile as the ones having a scientific basis and a strong imagination, and although not very practical, they are the ones that solve problems or suggest alternatives and innovative ideas. When a problem is really bad, one should rather wait and pray for an unpractical man. The more serious the trouble gets, the more probable it will be that some knowledge of scientific theory will be required (Chesterton (1874-1936) in Van Dorp $\&$ Monteros). Even though they are not practical, those with this profile become indispensable in the business world, insofar as their knowledge allows them to find creative alternatives for problems. The employable profile is defined as being sociable, flexible, tactful and only with knowledge about a specific subject. Its profile is sought because it works very well in a team. It is increasingly sought to develop innovative ideas in teams. Employability depends on so much more than explicit (subject specific) knowledge, but has a lot to do with personal skills and sociability. (Van Dorp \& Monteros, 2010). The entrepreneurial characteristic is referred to as mandatory for all students, because everyone should be able not only to produce ideas, inventions and discoveries, but should show as continuously investing in their training, so they are always up to date and bring along innovative strategies and visions. We must indeed strongly promote that students are equipped with the ability to induce change brought about byown discovery orinvention, or by adopting discoveries or inventions brought about by external drivers. (Van Dorp \& Monteros, 2010). Furthermore, these authors mention certain skills that students should acquire as being: (i) to generate, judge and validate knowledge; (ii) satisfy the human capital of the labour market; (iii) contribute to creation and innovation.

The student of today has digital culture, i.e., know how to use a large number of basic web tools for their day-to-day tasks, but to use these same tools for the acquisition and creation of knowledge is necessary, to first know how to reflect and know how to adapt knowledge in innovative ways. These competencies should be given by teachers, the latter having to master all the necessary skills in order to them pass them on to their students. The web 2.0 in learning, when applied correctly, can lead students to collaborative work, brainstorming and the construction of knowledge in cooperation. Emerging digital tools make it easier for students to ask and respond to each other's questions and for teachers to provide feedback in real-time (Johnson et al., 2014). It is up to the teacher, with the knowledge of the skills that students must acquire to enter easily in the world of work, to show students the impact that the proper use of these tools has on acquiring the knowledge and the skills essential for their future career.

\section{SOCIAL AND COLLABORATIVE ENVIRONMENTS IN E-LEARNING}

Since the appearance of email, in the 1990, ICT has evolved, today several formal learning management platforms are available to all, and with it the opportunity of accessing learning at a distance though online platforms, it has broken geographic and economic barriers for many, allowing a growth on lifelong learning as well. However even though these resources exist it does not mean that actual learning takes place for everyone. Certain skills are required to these learning experiences reach the high quality necessary, for the student as well as for the teacher, to this type of experience. In fact most say the teacher plays a decisive role in rising the platform to its full potential. As Thorpe (2005) says: the promise of the new media is just that - a promise or potential that can only be realised through skilled and creative design and teaching, on the part of both the local tutor and the course team. (...) lack of success in use of ICT 
may result as much from cultural differences in how people expect to learn, as from any feature of the new media themselves.

In addition to e-learning formal platforms, today's society, access to information and therefore to knowledge seems to be easier, as students have access to a wide variety of resources allowing formal, informal, non-formal and natural learning contexts, without leaving their homes. With the advent of Social and collaborative environments, students became more active and participative they not only access to contents but also create and share them, becoming reactive.

Communication has evolved, the new media allows now live conferencing, video sharing, social networking, collaborative tools, allowing the student to create, work collaboratively and communicate in a more direct way with their peers and their teachers. Instead of merely searching for information, applications such as bookmarking, feeds, tweeter and pinboards, digital portfolios, etc., along with the possibility of creating your own personal webpage, today's Web gives students also the chance to create a PLE. As Attwell (2007) mentioned, a PLE recognizes that learning is continuing and seeks to provide tools to support that learning. In a PLE the individual is responsible for the management of their own learning environment and for the selection of tools and contexts where learning will take place.

But for better understand how social and collaborative web can contribute to enhance e-learning first it's necessary to understand their individual characteristics.

Web 2.0 (or social Web) can be defined as the collaborative web - with an emphasis to online collaboration and sharing among users. As O’Reilly (2005) said, Web 2.0 is the collective intelligence of everyone who uses the web to upload, download, add comments, provide feedback, add tags and actively engage in the creation of new knowledge. Users are no longer only passive receptors of knowledge, they are active participators, by creat- ing, sharing and commenting content contribute to mass collaboration or collective intelligence (Lévy, 1994) and for wisdom of crowds (Surowiecki, 2005). For this to happen some principles must be implied (Tapscott \& Williams, 2008):

- Openness: By opening door to external ideas and agents, schools will outperform those who keep relying solely on their internal resources and capabilities;

- Peering: Peer-to-peer collaboration, in some tasks, might be more productive and knowledge generator than traditional hierarchical management;

- Sharing: Schools have to share part of their intellectual property so they can actively collaborate and generate new intellectual property plus improve their position in the global economy;

- Acting Globally: Globalization is nowadays a key concept, schools must act globally and in collaboration to stay at the top.

Tertiary education can have a significant gain and take benefits by integrating Web 2.0 and 3.0 tools into their traditional structures and procedures. Being by nature, globalized and collaborative these tools can benefit students and teachers when including online tools as a complement to face-to-face strategy.

Web 3.0 (or semantic Web) is related with immersive 3D virtual worlds where users connect, communicate and interact in real-time through their avatars (Hayes, 2006). Users learn and share in an immersive way - learning in $1^{\text {st }}$ person as opposed to $3^{\text {rd }}$. Some authors (Downes, 2010; Kop, 2010; Siemens, 2010; Wheeler, 2010) refer also to the eXtended Web (or Web x.0). Web x.0 seems to be directly connected with collective intelligence and the wisdom of crowds allowing anyone to learn at anytime and anyplace and in a personalized way. These new potentialities require the above mentioned skills, specifically related 
with (Wheeler, 2011): (i) social networking; (ii) privacy maintenance and identity management; (iii) creating, organising, reusing and repurposing content; (iv) filtering and selecting information; and (v) self-broadcasting.

Therefore, and according with Morrison (2011), graduates must be able to: (i) Function in a global economy for job success in the $21 \mathrm{st}$ century; (ii) Work effectively with people from different cultural backgrounds; (iii) Work as a team member; (iv) Use information technology tools effectively; (v) Function creatively and innovatively; (vi) Access, analyse, process, and communicate information; and (vii) Engage in continuous, independent learning.

\section{Virtual Learning Environments (VLE)}

Most tertiary education institutions have implemented LMS (Learning Management System), CMS (Open Source Course Management System) or VLE in order to better manage, organize and deliver learning contexts. By their nature VLEs are formal and closed environments, confined to a class, a course or a specific subject. Currently, the most popular VLE is Moodle (many times referred as LMS).

The focus of the Moodle project is always on giving educators the best tools to manage and promote learning (but) it needs to be installed on a web server somewhere (http://moodle.org/about).

Moodle is a space-based web application that integrates a set of features that allow you to create and manage a space for students to access content provided by the teacher, and where there is a diversity of interactions between the agents, synchronously and/or asynchronously. The main features of a VLE, in particular Moodle, are gathered in four dimensions (Alves \& Gomes, 2007):

- $\quad$ Protected access and management of user profiles - thus creating a web environment reserved for participants in a course and define the various permissions, at teachers and students level;

- Managing access to content, allowing teacher to put content online in various formats and set the times and ways how students can interact with them;

- Tools for synchronous and asynchronous communication, enabling communication between stakeholders;

- Means to control activities, allowing the registration of all activities / actions made by students and teachers.

VLEs facilitate student's access to information teachers make available, allows contact with peers and teachers through forums, chat rooms and message service. An additional modules makes it possible to do live video conferences. One other advantage of a VLE is making courses available to students in remote areas, or with scarce economic means. However, VLE visually have a static appearance, don't allow individual personalization and therefore it's not very motivating to students, especially those whose only contact with an institution is done through this virtual space.

Learning environments should encourage students to use meta-cognitive skills, reflect on relevant content in order to create knowledge. Therefore, to become more appealing, a VLE should be designed to address learners' diversity in terms of learning styles, prior knowledge, culture, and self-regulation skills (Vovides et al, 2007).

Since it is normal to be surrounded by all sorts of media and to use them simultaneously, a static place is poorly motivating to today's' students; and as they restricted environments, contributions and collaboration are limited to those attending the course. This limitation drives teachers to search for other more dynamic applications to complement the institutional VLE, like PLE. As Siemens (2012) refers planned information structures (...) 
simply can't adapt quickly enough to incorporate network-speed information development. Instead of being the hub of the learning experiences, books, courses, and classrooms become something more like a node in part of a much broader (often global) network.

\section{Personal Learning Environment (PLE)}

Besides VLEs, online learning can, nowadays, take advantage of other platforms and services available on the Web. Some of them have become very popular lately amongst students (and teachers) - such as social networks and virtual worlds. These virtual environments are open and visually more attractive - since they are graphically based. Social networks appear to be emerging environments providing channels of communication, sharing and distribution that enhance communication with e-learning students; these are beginning to replacing or supplement traditional communication with VLE (such as Moodle), ensuring the participation of the whole community.

With today's networks, students have access to live conferencing, video sharing, social networking, and collaborative tools - directly from their computers. Students can now create content, work collaboratively, socialize, interact and communicate in a more direct way with their peers and teachers. Instead of merely searching for information, applications such as bookmarking, RSS feeds, twitter and pinboards, digital portfolios, etc., along with the possibility of creating their own personal website, today's Web gives students the chance of creating their own Personal Learning Environment (PLE). As Attwell (2007) suggests, a PLE recognizes that learning is continuing and seeks to provide tools to support that learning. In a PLE students are responsible for the management of their own learning environment and for the selection of tools and contexts where learning will take place. According with Schaffert \& Hilzensauer (2008), learning with PLE implies certain changes, such as the role of the student as being more proactive and self-organized in constructing and sharing his own knowledge, supported by data retrieved from countless and varied information, made available by community peers; therefore social involvement plays an important role, as the more social software tools multiply sources and connections, therefore more information is attainable.

PLE are therefore environments undergoing continuing change, evolving not only with students' knowledge interests, but also keeping up with all new applications that appear on web.

For some academics PLE is an environment which aggregates all used tools, such as email, websites and applications; however, to a wider majority, a PLE is an environment containing social software application as well as web services, where students are able to gather information and produce knowledge and reflections. Furthermore, in such environment, students can make RSS feeds to follow the blogs and webpages he finds interesting. According to Schaffert and Hilzensauer (2008) PLE can be seen as mash-up in a single portal for the purpose of learning. (...) Examples for PLE applications are Netvibes 15 or WordPressMU16 (a multi user Weblog), but also I-Google17 or Flock18 could serve as a PLE. In short, a PLE is a set of Web 2.0 tools or services, gathered and chosen by the user, in a single webpage - which allow to derive for different other websites.

\section{VLEs and PLEs: Benefits for E-Learning Contexts}

An e-learning environment's main goal is to convey knowledge to anyone who wants to learn, regardless of where you are in the world. Most of the users look for e-knowledge due to geographical distance, economic limitations or limited time schedules. However few tend to follow through the entire course. Motivation is therefore one central topic when creating an environment for e-learning. 
VLE are nowadays more evolved, and allow more connectivity, such as synchronous chat rooms and live conferencing; however, connectivity in these spaces is always restricted to the ones who enroll in the course. Teachers try to make the place more inviting, making available a wide range of activities in order to motivate students for the course. In many situations they engage the help of tutors to deliver e-learning support. Tutors can perform a major impact in closed learning environments (such as LMS and VLE). They are responsible for course moderation, being a guide and a facilitator. Students can rely on tutors for their immediate feedback (Loureiro, Costa, Oliveira \& Barbas, 2011). Tutors help students' socialization, being a close peer in the learning process, maintaining class cohesion and high levels of motivation and participation.

In a personal learning environment learning is focused in the self; different from learning in a VLE, with only forums and text chat to communicate, and focused on a whole class or subject. With a PLE students are independent of a closed environment, but in a space where one can still collaborate, share, learn and search with a broader community, leading him to develop an attitude of independent learning. Furthermore, personal networks appear to be emerging environments providing channels of communication, sharing and distribution that enrich communication between e-learners. Students tend to create their own personal networks, engaging in different services, communities, groups and networks, according with their needs, interests, likes and motivations, looking for connections. This lead us into a modern learning approach, Connectivism, described as the learning theory for the digital age. This approach states that knowledge - and therefore the learning of knowledge - is distributive, that is, not located in any given place (and therefore not 'transferred' or 'transacted' per se) but rather consists of the network of connections formed from experience and interactions with knowing community (Downes, 2009).
According to Siemens (2004), theories most often used to describe the learning process, like Behaviorism, Cognitivism and Constructivism, do not take in account the way learning is impacted by technology, a fact one cannot ignore in the digital age we now live into. Technology already has reorganized how we live, how we communicate, and how we learn (Siemens, 2004), therefore, new age learning theories should consider the widely influence of social environments have on learning (especially in its informal and natural form), and reflect about the type of connections that the World Wide Web allows. As Vaill said, referred by Siemens, learning must be a way of being - an ongoing set of attitudes and actions by individuals and groups (Vaill, 1996), and so we must perceive the learning process which transforms experience into knowledge, skills, behaviors, and attitudes" (Cobb, 2009). To learn is to "acquire certain patterns" (Downes, 2009).

The connections within a personalized environment shape the knowledge one creates, by collecting and sharing information from varied sources, enriching the learners personal data collection, and contributing to the evolution of the students' learning profile from being a mere information gatherer to an active and reactive user, developing and sharing content and information, influencing the build of knowledge of the other users (Semantic Web). As social beings each one of us has an intrinsic need of being part a community, of being known by our peers, an unfulfilled eagerness for communication, and to share our ideas, needs and knowledge. We are now emerged in the real time, co-creative Web (Hayes, 2006). Students are now content builders, information sharers, communicators, belonging to a common space with no barriers, made of links, nodes and connections. Every day students establish new contacts, increasing their networks, sharing and collecting new information, rebuilding knowledge, and therefore learning (Loureiro \& Bettencourt, 2010). 


\section{FUTURE RESEARCH DIRECTIONS}

As digital technology continues to evolve, a wider range of technological solutions arise. Students are able to engage in different structures, groups and communities, making their own connections and creating their personal learning networks. As for the teacher, it is necessary to consider the students learning profiles and adopt teaching and learning strategies, which not only considers these profiles, but also equip students with the tools necessary to enter the today's work world.

VLEs emerged before the onset of web technology and enabled institutions to provide a structured environment for engaging students in a more flexible way than traditional (talk and chalk) methods, with the disadvantage that the environment is limited to a course, class or subject.

PLEs don't substitute learning management systems, as they are too unstructured from the learning management point of view, they rather act as a complement. They enlarge students' contact with valuable information sources, allowing to share and construct knowledge while constantly reshaping and updating it.

With the combination of VLE and PLE, the following learning scenario emerge (Figure 4). A Teacher initiates a learning task in the VLE which the student imports into his own PLE, the student can then engage with his socially connected learning network to explore the topic then deliver the result of that process back to the VLE on completion of the task. It is not the concern of the teacher what tools are used to build the PLE, but only that the student engages with a wider network to enhance his own learning. In terms of learning, we can say it starts in the formality of a classroom and follows in the informality of the Web.

\section{CONCLUSION}

In an interconnected society access to information, content creation and knowledge sharing are at a distance of a click. Access to learning contexts is

Figure 4. Learning scenario

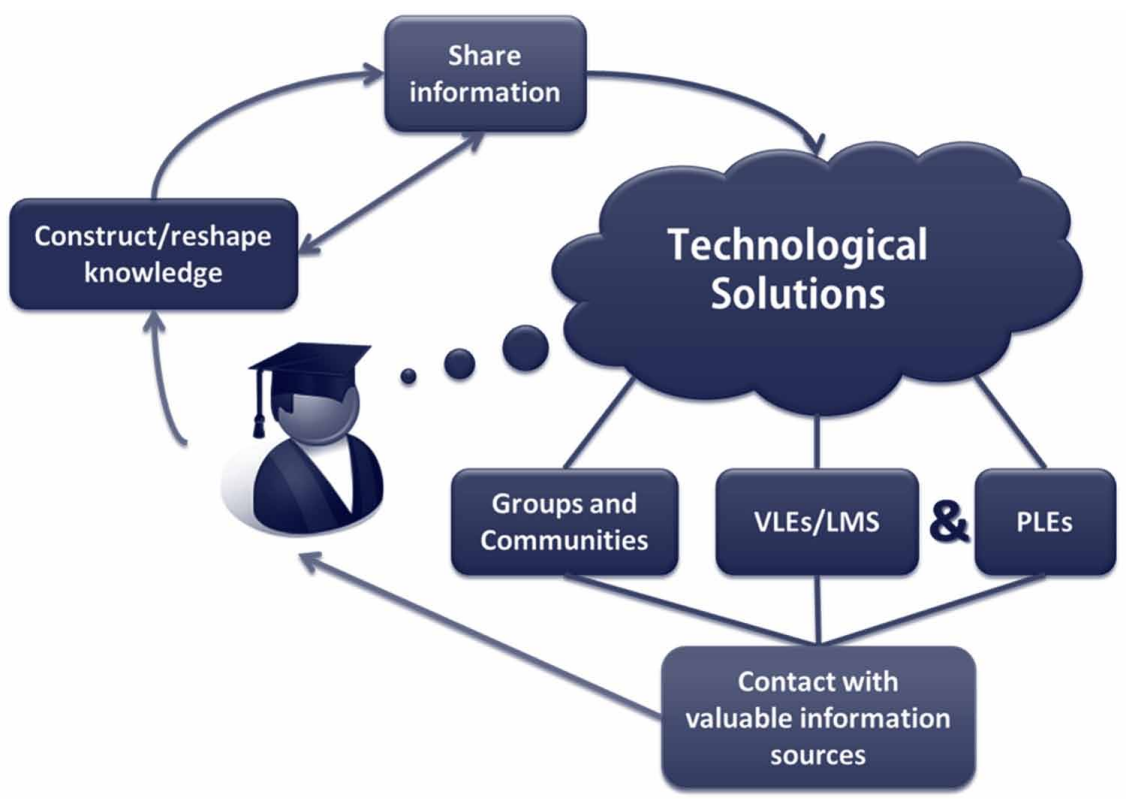


equally easy. E-Learning is a reality for a foreseeable future. Social Web and collaborative virtual environments are already making changes in the way students learn. In fact, socialization is a key factor for collaborative and social learning - and that means connecting, communicating, interacting and establishing relationships (Loureiro, Bettencourt \& Santos, 2011). To know how, where, when and with whom to socialize is becoming a vital skill, as well as to know where, what and how to look for and share information. To do this students also have to be in possess of digital skills, in order to face the networked society they live into. To be connected, collaborative, have digital literacy and critical thinking is mandatory. Almost everything we do nowadays requires computer mediation. Nevertheless, the ability for conflict resolution and negotiation, to communicate and express ideas, for creative problem solving and strategic thinking are also very important - interpersonal or soft skills (emotional intelligence). It is common to say that hard skills will get you an interview but you need soft skills to get and keep the job (Smith, 2011). At this moment, and due to society's demands, the sentence can be rephrased into: hard skills will get you an interview but you need e-skills and soft skills to get (and keep) the job. E-learning, through the use of social web and collaborative virtual environments, can be used to develop and enhance these competences on students, especially at tertiary education. Many learning contexts of role playing and simulation can be created for students to experience a wide range of situations and therefore apply them to real life contexts.

\section{REFERENCES}

Allen, I.E., \& Seaman, J. (2010). Learning on Demand. Sloan Consortium. Retrieved from http://sloanconsortium.org/publications/survey/ learning_on_demand_sr2010
Alves, A. P., \& Gomes, M. J. (2007). O ambiente Moodle no apoio a situações de formação não presencial. In Challenges 2007 : actas da $V$ Conferência Internacional de Tecnologias de Informação e Comunicação na Educação (pp. 337-349). Braga.

Attwell, G. (2007). Personal Learning Environments - the future of eLearning? eLearning Papers, 2(1). Retrieved from http://citeseerx.ist.psu.edu/ viewdoc/download?doi=10.1.1.97.3011\&rep=r ep1\&type $=$ pdf

Bettencourt, T. (2010). Second Life $®$ - Uma nova forma de expressão de arte. In U. de Múrcia \& U. Aberta (Eds.), VI Seminário Imagens da Cultura / Cultura das Imagens. Porto: Universidade Portucalense.

Carstens, A., \& Beck, J. (2005). Get Ready for the Gamer Generation. TechTrends: Linking Research and Practice to Improve Learning, 49(3), 22-25. Retrieved from [REMOVED HYPERLINK FIELD]http://www.nslg.net/Get Ready For The Gamer Generation.pdf

Castells, M. (2005). The Network Society - A cross-cultural perspective. (M. Castells, Ed.) (Vol. 59). Massachusetts: Edward Elgar Publishing, Inc. doi: $10.2307 / 778114$

Cobb, J. (2009). Definition of Learning. Mission to Learn. Retrieved from http://www.missiontolearn. com/2009/05/definition-of-learning/

Colardyn, D., \& Bjornavold, J. (2004). Validation of Formal, Non-Formal and Informal Learning: policy and practices in EU Member States. European Journal of Education, 39(1), 69-89. Retrieved from http://citeseerx.ist.psu.edu/viewdoc/downlo ad?doi=10.1.1.513.7835\&rep=rep1\&type $=$ pdf

Cross, J. (2009). Informal Learning 2.0. Internet Time Blog. Retrieved from http://www.internettime.com/2009/08/informal-learning-2-0/ 
Downes, S. (2009). Learning Networks and Connective Knowledge. In Collective Intelligence and E-Learning 2.0: Implications of Web-Based Communities and Networking. doi:10.4018/9781-60566-729-4.ch001

California ICT Digital Literacy Assessments and Curriculum Framework. (2008). CET Fund. Retrieved from http://www.ictliteracy.info/rf.pdf/ California ICT Assessments and Curriculum Framework.pdf

Hayes, G. (2006). Virtual Worlds, Web 3.0 and Portable Profiles. Personalize media. Retrieved from http://www.personalizemedia.com/virtualworlds-web-30-and-portable-profiles/

Howe, N., \& Strauss, W. (2000). Millennials Rising: The Next Great Generation. New York: Vintage Books.

Introduction to Information Literacy. (2010). Association of College \& Research Libraries (ACRL). Introduction to Information Literacy. Retrieved from http://www.ala.org/acrl/issues/ infolit/intro

Johnson, L., Adams Becker, S., Estrada, V., Freeman, A., Kampylis, P., Vuorikari, R., \& Punie, Y. (2014). Horizon Report Europe 2014 (Schools ed.). doi:10.2791/83258

Jones, C., \& Shao, B. (2011). The Net Generation and Digital Natives: Implications for Higher Education. Retrieved from http://www.heacademy. ac.uk/assets/documents/learningandtech/nextgeneration-and-digital-natives.pdf

Jones-Kavalier, B. R., \& Flannigan, S. L. (2006). Connecting the Digital Dots: Literacy of the 21st Century. EDUCAUSE Quarterly, 2, 8-10. Retrieved from http://er.educause.edu/ /media/ files/article-downloads/eqm0621.pdf

Jorgensen, B. (2003). Baby Boomers, Generation $\mathrm{X}$, and Generation Y: Policy Implications for Defence Forces in the Modern Era. Foresight, 5(4). doi:1463-6689
Kop, R. (2010). The eXtended Web and the Personal Learning Environment. Retrieved from http://ritakop.blogspot.pt/2010/07/extended-weband-personal-learning.html

Lenhart, A., Rainie, L., \& Lewis, O. (2001). Teenage life online: The rise of the instant-message generation and the Internet's impact on friendships and family relationships. Pew Internet \& American Life Project. Retrieved from http://www.pewinternet.org/files/old-media/Files/Reports/2001/ PIP_Teens_Report.pdf.pdf

Lévy, P. (1997). Collective Intelligence. Cambridge, Massachusetts: Helix books; Perseus Books. Retrieved from https://is.cuni.cz/studium/ predmety/index.php?do=download\&did $=29658$ \&kod=JJM085

Loureiro, A., \& Bettencourt, T. (2010). Immersive Environments - A Connectivist Approach. In M. D. Lytras, P. Ordonez De Pablos, A. Ziderman, A. Roulstone, H. Maurer, \& J. B. Imber (Eds.), Knowledge Management, Information Systems, E-Learning, and Sustainability Research (Vol. 111, pp. 202-2014). Berlin, Heidelberg: Springer Berlin Heidelberg; doi:10.1007/978-3-64216318-0_24

Loureiro, A., Costa, C., Oliveira, N., \& Barbas, M. (2011). E-moderation in virtual environments - enhancing e-learning contexts in higher education. Proceedings ofICERI2011 (pp.3635-3643). Retrieved from http://library.iated.org/view/ LOUREIRO2011EMO

Loureiro, A., Santos, A., \& Bettencourt, T. (2012). Virtual Worlds as an Extended Classroom. In C. S. Lányi (Ed.), Applications of Virtual Reality (p. 89). InTech; Retrieved from http://cdn.intechopen. com/pdfs-wm/36540.pdf doi:10.5772/35595

Martin, A., \& Ashworth, S. (2004). Welcome to the Journal of eLiteracy! JeLit - Journal of eLiteracy, 1, 2-6. Retrieved from http://www.jelit. org/11/01/JeLit_Editorial.pdf 
McCormack, a. (2010). The e-Skills manifesto. A Call to Arms. Brussels, Belgium: European Schoolnet. Retrieved from http://www.imasdtic. net/CLI_AETIC/ftpportalweb/documentos/eskills_manifesto.pdf

Morrison, J. (2011). The changing Landscape of American and Malaysian Higher Education. Retrieved from http://horizon.unc.edu/projects/ presentations/HiED in transition.pdf

New Generations at Work: Attracting, Recruiting, Retraining \& Training Generation Y. (2006). McCrindle Research. Retrieved from http://mccrindle.com.au/resources/whitepapers/ McCrindle-Research_New-Generations-AtWork-attracting-recruiting-retaining-traininggeneration-y.pdf

O'Reilly, T. (2005). What Is Web 2.0 - Design Patterns and Business Models for the Next Generation of Software. O'REILLY. Retrieved from http://www.im.ethz.ch/education/HS08/ OReilly_What_is_Web2_0.pdf

Oblinger, D., Oblinger, J., Roberts, G., McNeely, B., Windham, C., \& Hartman, J. ... Dede, C. (2005). D. Oblinger \& J. Oblinger, (Eds.), Educating the net generation: A Handbook of findings for practice and policy. Educause. Retrieved from http://www.netgen.unimelb.edu.au/downloads/ handbook/NetGenHandbookAll.pdf

Palfrey, J., \& Gasser, U. (2008). Born Digital: Understanding the First Generation of Digital Natives. New York: Basic Books; Retrieved from http://pages.uoregon.edu/koopman/courses_readings/phil123-net/identity/palfrey-gasser_borndigital.pdf

Prensky, M. (2001). Digital Natives, Digital Immigrants, Part II: Do They Really Think Differently? On the Horizon, NCB University Press, 9(6). Retrieved from http://www.marcprensky. com/writing/Prensky-Digital Natives, Digital Immigrants - Part2.pdf
Prensky, M. (2009).H. Sapiens Digital:From Digital Immigrants and Digital Natives to Digital Wisdom. Innovate. Retrieved from http://stevekolb. files.wordpress.com/2010/01/digital-wisdom.pdf

Prensky, M. (2012). From Digital Natives to Digital Wisdom. In From Digital Natives to Digital Wisdom: Hopeful Essays for 21st Century Education. California: Corwin - A SAGE company. Retrieved from http://marcprensky.com/writing/ Prensky-Intro_to_From_DN_to_DW.pdf

Prensky, M. (n. d.). Digital Natives, Digital Immigrants. On the Horizon, 9(5). Retrieved from http://www.marcprensky.com/writing/PrenskyDigital Natives, Digital Immigrants - Part1.pdf

Rosen, L. D., Carrier, M. L., \& Cheever, N. A. (2010).L. D. Rosen(Ed.), Rewired Understanding the iGeneration and the Way They Learn. New York: Palgrave Macmillan. Retrieved from http:// english.360elib.com/datu/L/EM360415.pdf

Rowlands, I., Nicholas, D., Williams, P., Huntington, P., Fieldhouse, M., Gunter, B., \& Tenopir, C. etal.(2008). The Google generation: The information behaviour of the researcher of the future. Aslib Proceedings: NewInformation Perspectives, 60(4), 290-310. doi:10.1108/00012530810887953

Schaffert, S., \& Hilzensauer, W. (2008). On the way towards Personal Learning Environments: Seven crucial aspects. eLearning Papers, 9.

Schulz, B. (2008). The Importance of Soft Skills: Education beyond academic knowledge. Nawa: Journal of Language and Communication, 2(1), 146.

Siemens, G. (2004). elearnspace. Connectivism: A Learning Theory for the Digital Age. Elearnspace. Retrieved from http://www.elearnspace. org/Articles/connectivism.htm

Siemens, G. (2010). web 3.0/xWeb. Elearnspace. Retrieved from http://www.elearnspace.org/ blog/2010/09/30/web-3-0xweb/ 
Siemens. (2012). Openness: Why learners should know about, and influence, how decisions are made about their learning. Elearnspace. Retrieved from http://www.elearnspace.org/blog/2012/02/10/ openness-why-learners-should-know-about-andinfluence-how-decisions-are-made-about-theirlearning/

Smith, T. (2011). The Growing Importance of Soft Skills I Little Things Matter. Little Things Matter. Retrieved from http://www.littlethingsmatter. com/blog/2011/02/08/the-growing-importanceof-soft-skills/

Strauss, W., \& Howe, N. (1991). Generations: The History of America's Future, 1584 to 2069. New York: William Morrow and Company.

Strauss, W., \& Howe, N. (2003). Millennials Go to College: Strategies for a New Generation on Campus (2nd ed.). New York: American Association of Collegiate Registrars.

Surowiecki, J. (2005). The Wisdom of Crowds. First Anchor Books. Retrieved from https://gsappworkflow2010.files.wordpress.com/2010/09/ wisdom-of-crowds_surowiecki-1.pdf

Tapscott, D. (1998). Growing Up Digital. US: McGraw-Hill Inc. Retrieved from http://dontapscott.com/books/growing-digital/

Tapscott, D. (2009). Characteristics if a Generation: The Eight Net Gen Norms. In Grown Up Digital: how the net Generation is changing your world (pp. 73-96). McGraw-Hill.

Tapscott, D., \& Williams, A. D. (2008). Wikinomics - How Mass Collaboration Changes Everything. New York, NY, USA: Penguin Group; Retrieved from http://www.labeee.ufsc.br/ luis/ egcec/livros/globaliz/Wikinomics.pdf
Thorpe, M. (2005). The impact of ICT on lifelong learning. In C. Mcintosh (Ed.), Perspectives on distance education-Lifelong Learning \& Distance Higher Education (pp. 23-32). Commonwealth of Learning; Unesco. Retrieved from http:// portal.unesco.org/education/es/file_download. php/b261185b2d732746bc0615eb2b9fdfc6LLL_ DHE.pdf

Vaill, P. B. (1996). Learning as a Way of Being: Strategies for Survival in a World of Permanent White Water. Retrieved from http://www.amazon. com/Learning-Way-Being-Strategies-Permanent/ $\mathrm{dp} / 0787902462$

Van Dorp, C. A., \& Monteros, A. H. (2010). Challenges of Open and Distance Learning in the Post-2010 Decade: Scenarios for Institutional Innovation. eLearning Papers, 18.

Vovides, Y., Sanchez-Alonso, S., Mitropoulou, V., \& Nickmans, G. (2007). The use of e-learning Course Management Systems to support learning strategies and to improve self-regulated learning. Elsevier. Educational Research Review, 2(1), 64-74. Retrieved from http://www.cc.uah.es/ ssalonso/papers/EducationalReviewDraft.pdf doi:10.1016/j.edurev.2007.02.004

Weiler, A. (2005). Information-Seeking Behavior in Generation Y Students: Motivation, Critical Thinking, and Learning Theory. Journal of Academic Librarianship, 31(1), 46-53. Retrieved from http://php.scripts.psu.edu/students/j/m/ jmd394/saw4/infoseek/infoseekinggenx.pdf doi:10.1016/j.acalib.2004.09.009

Wheeler, S. (2010). Web 3.0: The Way Forward? Learning with "e"s - My thoughts about learnig technology and all things digital. Retrieved from http://steve-wheeler.blogspot.pt/2010/07/web-30way-forward.html 
Wheeler, S. (2011). The Future of Learning: Web 2.0 and the Smart eXtended Web. Retrieved from http://www.slideshare.net/timbuckteeth/thefuture-of-learning-6809148

\section{KEY TERMS AND DEFINITIONS}

Digital Literacy: A group of competences that allows an individual to acquire knowledge through digital processes.

Digital Literate: Does not refers only to the capability to use a computer or an email, but to the capability to gather, understand, interpret and share information available in all digital media. Being digital literate gives us the ability to communicate and work more efficiently, because it involves understanding how all digital devices work and how they can be used to interact with society.

Formal Learning: Occurs essentially when a student attends to class in a formal institution. And is the one we use for most of our student life as it may confer a formal recognition in the form of a certificate or diploma.

Informal Learning: Can be defined as a result of doing daily activities. It is not organised nor has a formal recognition, for it can be made during daily tasks, such as observation, asking questions, trial and error, and sometimes it can even be accidental.
Information Literacy: Comprehends knowledge of one's needs and problems with information, and the ability to identify, locate, evaluate, organize and create, use and communicate effectively the information to solve existing problems or issues.

Literacy: The ability to comprehend what we read, to give meaning, and to understand written language. Not having any relation to the fact of one being educated or not.

Natural Form of Learning: The learning process is individual and occurs because the learner wants to learn independently of the time/place they are in, at their own pace and in an autonomous way; depends on the level of socialization an individual can carry out - more the socialization more the person will learn.

Non-Formal Learning: Can be referred as semi-organized and intentional, meaning it may or may not have organised activities but that it has a learning objective.

Social Skills: The set of skills that allow students to communicate, relate and socialize with others.

Soft Skills: Personality traits, qualities and also social skills which every student possesses although in varying degrees - it is related with emotional intelligence. 